WellBeing International

WBI Studies Repository

1987

\title{
Industry Toxicologists Keen on Reducing Animal Use
}

Constance Holden

Follow this and additional works at: https://www.wellbeingintlstudiesrepository.org/henspro

Part of the Animal Experimentation and Research Commons, Bioethics and Medical Ethics Commons, and the Laboratory and Basic Science Research Commons

\section{Recommended Citation}

Holden, C. (1987). Industry toxicologists keen on reducing animal use. Science, 236, 252-253.

This material is brought to you for free and open access by WellBeing International. It has been accepted for inclusion by an authorized administrator of the WBI Studies Repository. For more information, please contact wbisr-info@wellbeingintl.org.

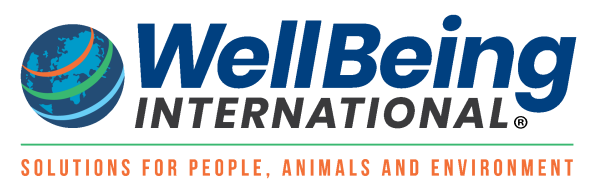




\title{
Industry Toxicologists Keen on Reducing Animal Use
}

\author{
Constance Holden
}

Prodded by the animal welfare movement, major manufacturers of pharmaceuticals, pesticides, and household products have made significant advances in recent years toward the goal of reducing the number of animals used in toxicity testing. Alternative methods, such as cell and tissue culture and computer modeling, are increasingly being seen not just as good public relations but as desirable both economically and scientifically.

One of the corporate movers in this area is Myron Mehlman, director of toxicology at Mobil Oil Corporation. Mehlman invited a group of toxicology directors to an informal meeting in Princeton, New Jersey, in early April to assess progress. Also at the meeting were officials from the Food and Drug Administration (FDA) and the Environmental Protection Agency (EPA), as well as Henry Spira, the animal activist whose coalition to stop use of the Draize eye irritation test started the ball rolling and led to the formation of industry-funded research centers at Johns Hopkins and Rockefeller universities.

Progress so far has been impressive, particularly in the area of acute toxicity testing. Charles F. Reinhardt of DuPont reported, for example, that his company has reduced the number of animals in acute studies by $60 \%$. Part of this has been achieved through a modified Draize test, which uses only two rabbits per test and involves a tenfold reduction in the concentration of compounds tested on their eyes. Robert Kapp of Exxon reported good correlations with existing Draize data on 30 different compounds with the use of two in vitro tests. Carl R. Mackerer of Mobil said that a modified Ames test--a preliminary screening test for mutagenicity and carcinogenicity--can be used to replace a 30-year-old test for dermal carcinogenicity of naphthenic oils.

Gary Flamm, director of the FDA Office of Toxicology Sciences, said that the LD50 (the heavily criticized test in which lethality is proven if a substance kills half of a test population) should be replaceable in the vast majority of cases, and that most Draize tests could be done away with. He said revision of Bureau of Foods testing guidelines will probably include requirements for smaller numbers of animals in test groups and will probably delete details on LD50 testing so it will "stand as a discouragement rather than a recipe for it."

As for long-term toxicity testing, Flamm predicted that large animal tests for carcinogencity will be "all but passe" in the next 10 to 15 years with advances in oncogene research, which will make it possible to identify "biomarkers" for cancer potential in smaller groups of animals over shorter periods of time.

Regulatory change has been slow, but there has been flexibility added to cumbersome requirements. For example, Emil A. Pfitzer of Hoffinann-La Roche said new toxicity tests used to be required if a company wanted to "change the shape or color of a pill." Flamm said that 10 years ago, his agency would have required that the dye used in colored contact lenses be tested on animal eves at 100,000 times the concentration in the contact. Now, he said, the lens itself is tested on animal eyes. 
Unnecessary testing is still wasting a lot of animals, not only because of outmoded requirements but because much existing information is not easily accessible. Theodore M. Farber, director of EPA's Toxicology Branch, said that his agency has files of 42,000 completed tests, and 16,000 LD50 tests. He said these could be of far more use in eliminating redundant tests if they were computerized for easy accessibility. "Many of us in regulatory toxicology see the same studies over and over again," said Farber.

Another problem is lack of uniformity in toxicity testing guidelines, both among U.S. agencies and internationally. In many cases, the differing guidelines of different countries constitute what amounts to nontariff trade barriers, a problem particularly evident with Japan. "There is no justification for the international multitude of guidelines," said Pfitzer, who called for "global protocols." Mehlman proposed the formation of a commission made up of scientists and regulatory agency representatives to develop some authoritative guidance that would be listened to by U.S. agencies and perhaps influence some action by the Organization for Economic Cooperation and Development.

There was general agreement that impetus for continued progress cannot be expected from government bodies but must come from scientists themselves. Said Flamm: "In the final analysis, what the scientific community says its consensus is what counts."

\section{Recommended Citation:}

Holden, C. (1987). Industry toxicologists keen on reducing animal use. Science, 236, 252-253. 